\title{
NCOA6 wt Allele
}

National Cancer Institute

\section{Source}

National Cancer Institute. NCOA6 wt Allele. NCI Thesaurus. Code C52143.

Human NCOA6 wild-type allele is located in the vicinity of $20 q 11$ and is approximately 111 $\mathrm{kb}$ in length. This allele, which encodes nuclear receptor coactivator 6 protein, is involved in transcriptional regulation. 